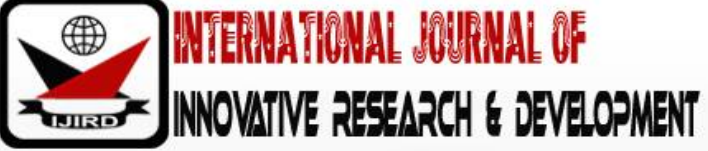

ISSN 2278 - 0211 (Online)

\section{Age-Related Differences in Academic Performance of Undergraduate Science Courses at the University of Nairobi, Kenya}

\author{
Lydiah N. Wambugu \\ Senior Lecturer, Department of Odel Campus, \\ University of Nairobi, Kenya \\ E. Adenike Emeke \\ Professor, Department of Educational Evaluation \\ University of Ibadan, Nigeria
}

\begin{abstract}
:
The emergence of global-based knowledge economies has generated a world-wide demand for higher education among adults and tertiary age school graduates. Among the adults, there is quest for life-long learning in order to upgrade skills and maintain competitiveness within the rapidly evolving economies. This demand is not limited to the adults only but also among the young who view education as a means for realizing social, cultural, economic and political needs and aspirations. In this paper, the researchers explored the relationship between age and academic performance by comparing the performance of third year students in the Bachelor of Education (Science) on-campus mode of learning relative to those enrolled in the Open and Distance Learning (ODL) mode at the University of Nairobi. Results indicate that the on-campus students performed significantly better than the ODL students in Chemistry and Biology; $\mathrm{t}_{(44)}=$ 4.427, $\mathrm{p}<05$ and $\mathrm{t}_{(65)}=-8.54, \mathrm{p}<05$ respectively. In Physics, on-campus students had a higher mean score of 54.22 against 54.04 of the ODE students. The difference in the means was not significant; $t_{(71)}=.120, p>05$. However, there was no significant relationship between age and academic performance. The researchers conclude that age does not influence academic performance. Therefore, enhanced academic performance may be a matter of personal determination rather than age determined.
\end{abstract}

Keywords: Age, open and distance education, on-campus and distance learning, academic performance

\section{Introduction}

Over the past decade, demand for higher education has contributed to the growth and development of Open and Distance Learning (ODL). This has in return increased student enrollment in higher education disciplines including science programs that were conventionally restricted to classrooms and laboratories. ODL has thus become an indispensible learning and business tool regardless of the discipline (Mapuva, 2009). Although the convenience of ODL is worthy of consideration, student achievement should be the primary concern. The importance of scholastic and academic performance has raised important questions for educational researchers. These include: Does age promote or predict academic performance among learners? Is there a significant difference in academic performance between learners in the face to face mode and those in ODL? An answer to these questions is critical to inform policies that govern higher education. For instance, parents and students would wish to be assured that that the mode of leaning will not limit the student in his/her future endeavors. The employers and especially the Teachers Service Commission would be comfortable employing a teacher who has gone through face to face as well as those who have gone through ODL because the quality of the graduate teacher is similar. In this study, academic performance is operationalized as the overall average mark or grade obtained by a learner in the final examination in each of the following subjects in year one, year two and year three at the University of Nairobi; Chemistry, Biology and Physics.

The development of any educational system, whether conventional or distance, presupposes some conception of the type of students to be served and their educational needs. This conception is referred to as a student archetype (Powell, McGuire \& Crawford, 1999, p. 89). Conventional institutions are designed to serve 'front-end' learners, those entering the system directly from secondary education (Ding, 1999). In contrast, distance teaching universities both local and international target adults who had not been able to, or did not, take advantage of conventional higher education in their youth and could not use the conventional system in their later years (Mills \& Tait, 1999). This group of students is generally referred to as non-traditional students and constitutes the distance study group. According to Keegan (1996), these students tend to be gainfully employed, and are older as compared to the traditional students. 
At the University of Nairobi, ODL admits students who are mainly adults with other social and personal responsibilities competing for study time. On-campus students are comparatively younger and have all their time dedicated to learning. Ding (1999) describes the on-campus students as the 18-24-year-old front-end learners whose engagement in education is the primary, if not the exclusive, occupation of these students. Powell, McGuire and Crawford (1999) describes distance learners as participants in the labor force and who do not have the luxury of devoting themselves solely to the pursuit of education. The responsibilities of the ODE students coupled with limited study time may impact negatively on their performance. Age of the individual, as it increases usually affects the various developmental changes of human performance. In addition, it is often said that, older students, being more highly motivated and more experienced in many realms of life, should obtain higher grade point average (McEvoy, 2003). Various educators have attempted to explain the relationship between age and academic performance. For instance, Okoh (2010) explains that distance study students perform better than on-campus students because cognitive development and maturity which are associated with age are necessary for a worthwhile performance of the students. Secondly, distance study students are more mature in terms of age and experience and they therefore bring diverse accumulation of knowledge into the learning process which in turn may buttress their academic performance.

King and Doerfert (1995) performed a descriptive experiment that followed 112 Bachelor of Arts students aged 19 to 57 who were enrolled in courses delivered by videotape, interactive video and face-to- face. The researchers expected the older students to perform better than the younger ones, but the findings were different. The results showed a no significant difference on academic performance based on age $(p=0.654, p>.05)$. The plausible reason, explained the researchers was drawn from Piaget Theory (1932) which states that at adolescent, the individual brain is fully developed and can get involved in complex as well as abstract thinking and from Michael Knowles Theory of Adult Learning (1937) which states that older students (adults) tend to be more focused, self driven and self-motivated and higher education is central to fulfilling their aspirations. Neumann and Shachar (2010) investigated creativity, age and gender as predictors of academic achievement among under graduate students of American Universities. A sample of 154 (105 males and 48 females) students completed creativity test. Cumulative Grade Point Average (CGPA) of the selected participants was used. Multiple regression analysis showed interaction effects between creativity, age and gender as lower predictors of academic achievement. No significant difference between CGPA and age was observed. Be are (1999) conducted a study on medical students and the result showed that there was a significant relationship between scores in examinations and age.

\subsection{Statement of the Problem}

There has been numerous researches and findings on the relationship between age and academic performance. However, there is still gap in knowledge on age as a predictor of academic performance. While some research findings support age as predictor of academic performance, others have failed to find any relationship between this predictor and academic performance. This then implies that there is inadequate comparative research output that would inform the growth of the two modes of learning. This study assesses whether age differences between on-campus (face to face) and ODL learners is a predictor of academic performance in Bachelor of Education (Science) at the University of Nairobi.

\subsection{Research Question}

In a comparative manner, this study sought to answer the following research questions:

- What is the difference in mean score performance in (i) Chemistry, (ii) Physics and (iii) Biology end of year examinations between Bachelor of Education (Science) on-campus and Bachelor of Education (Science) distance learners?

- What is the relationship between age and academic performance of Bachelor of Education (science) learners in distance and on-campus mode of learning?

\subsection{Hypothesis}

The study also tested the following hypotheses:

- $\mathrm{H}_{1}$ : There is a significant difference in mean score performance in (i) Chemistry, (ii) Physics and (iii) Biology end of year examinations between Bachelor of Education (Science) on-campus and Bachelor of Education (Science) distance learners;

- $\mathrm{H}_{1}$ : There is a significant relationship between mode of learning and academic performance of Bachelor of Education (Science) on-campus and distance learners;

- $\mathrm{H}_{1}$ : There is a significant relationship between age and academic performance of Bachelor of Education (Science) on-campus and distance learners.

\section{Research Methodology}

This study employed a correlational survey design where simple random sampling design was used to select 50 ODL and 131 on-campus students from a population of 57 ODL and 195 on-campus third year B.Ed. (Science) students respectively. The main instrument of data collection was document analysis guide.

\section{Data Analysis and Results}

The following section focuses on data analysis, interpretation and discussions of findings. Three key variables are analyzed; age, differences in academic performance and finally relationship between age and academic performance. 3.1. Age Distribution of the B.Ed. ( Science) Students 
As presented in Table 1, majority of the ODL students (54.0\%) were aged between 30-34 years while majority of the on-campus students (80.2\%) were aged between 20-24 years. This finding suggests that ODE offered a second chance to older people who may have been locked out of institutions of higher learning while on-campus attracted students direct from secondary schools. Other scholars had found similar trends. Ding (1999) describes on-campus students as the 18-24year-old front end learners who proceed to the university from secondary education and whose engagement with education is the primary, if not their exclusive occupation. Unterberg (2004) describes ODL students as nontraditional students over the age of 25 years. Clinton (2005) describes distance learners as working adults between 20-65 years of age with an average of 32 years. This finding seems to also suggest that on-campus students belong to an age group where generally one has not assumed parental responsibilities whereas the ODL students are more mature and may have other personal and social responsibilities that may interfere with their learning.

\begin{tabular}{|c|c|c|c|c|}
\hline \multicolumn{2}{|c|}{ Distance Study Students } & \multicolumn{3}{|c|}{ On-campus Students } \\
\hline Age group & Frequency & Percentage & Frequency & Percentage \\
\hline $20-24$ & 3 & 6.0 & 105 & 80.2 \\
\hline $25-29$ & 9 & 18.0 & 24 & 18.3 \\
\hline $30-34$ & 27 & 54.0 & 1 & 0.8 \\
\hline $35-39$ & 11 & 22.0 & 1 & 0.8 \\
\hline Total & 50 & 100.0 & 131 & 100.0 \\
\hline
\end{tabular}

Table 1: Age Distribution of the B.Ed. (Science) Students

The students were then asked to rate in their own opinion, the level at which age affects academic performance. The responses are summarized in Table 2.

\begin{tabular}{|c|c|c|c|c|}
\hline \multirow{2}{*}{ Rating } & \multicolumn{2}{|c|}{ ODL Learners } & \multicolumn{2}{c|}{ On-Campus Learners } \\
\cline { 2 - 5 } & \multicolumn{2}{|c|}{ Age } & Age \\
\cline { 2 - 5 } & Frequency & Percentage & 81 & Percentage \\
\hline High & 23 & 46.0 & 28 & 21.8 \\
\hline Average & 19 & 38.0 & 22 & 16.8 \\
\hline Low & 8 & 16.0 & 131 & 100.0 \\
\hline TOTAL & 50 & 100.0 & \\
\hline
\end{tabular}

Table 2: Level at Which Age Affects Academic Performance

Twenty-three (46.0\%) ODL students and 81 (61.8\%) on-campus students rated age as a variable that highly influences academic performance. The students were then asked through an open-ended question to explain their rating. The reasons given for this rating are tabulated in Table 3.

\begin{tabular}{|l|c|c|c|c|}
\hline \multicolumn{1}{|c|}{ Variable } & Distance Study Students & \multicolumn{2}{c|}{ On-Campus Students } \\
\cline { 2 - 5 } & Frequency & Percentage & Frequency & Percentage \\
\hline \multicolumn{1}{|c|}{ AGE } & & & & \\
\hline a) Young people grasp concepts faster than older people & 30 & 60.0 & 82 & 63.0 \\
\hline b) Older people are more motivated to work hard & 14 & 28.0 & 36 & 27.5 \\
\hline $\begin{array}{l}\text { c) Older people have other responsibilities that } \\
\text { interfere with learning }\end{array}$ & 24 & 48.0 & 12 & 9.2 \\
\hline d) Both have the potential to perform well & 6 & 12.0 & 20 & 15.3 \\
\hline
\end{tabular}

Table 3: Students' Response on the Reasons for Their Rating

$$
\mathrm{N}=50 \text { ODL and } 131 \text { on-Campus Learners }
$$

3.2.Hypothesis 1: Difference in Academic Performance between B.Ed. (Science) On-Campus and ODL Students in (I) Chemistry, (Ii) Biology And (Iii) Physics

To determine the differences in academic performance, the researchers determined the performance of the B.Ed. (Science) students in year one, two and three by averaging the scores awarded in semester one and two per academic year. The researchers then determined the overall students' performance by finding the average of the scores in year one, two and three. Table 4 presents findings of the overall mean performance of the B.Ed. (Science) students in the two modes of learning.

\begin{tabular}{|c|c|c|c|c|}
\hline Subject & N & Distance Learning & N & On-Campus \\
\hline Chemistry & 10 & 51.73 & 36 & 59.47 \\
\hline Biology & 28 & 48.31 & 34 & 58.61 \\
\hline Physics & 12 & 54.04 & 61 & 54.22 \\
\hline
\end{tabular}

Table 4: Mean Performance of the B.Ed. (Science) Students 
As Table 4 shows, shows the mean performance of the on-campus students in the three science subjects was higher than for the ODL students. The difference in means was tested using independent t-test as shown in Table 5

\begin{tabular}{|c|c|c|c|c|c|c|}
\hline \multirow{2}{*}{} & \multicolumn{2}{|c|}{$\begin{array}{c}\text { Levene's Test for } \\
\text { Equality of Variances }\end{array}$} & \multicolumn{2}{|c|}{ t-test for Equality of Means } \\
\cline { 3 - 7 } & $\mathbf{F}$ & Sig. & t & df & Sig. (2-tailed) \\
\hline $\begin{array}{c}\text { Overall mean score } \\
\text { performance in Chemistry }\end{array}$ & $\begin{array}{c}\text { Equal variance } \\
\text { assumed }\end{array}$ & .044 & .835 & -4.427 & 44 & .000 \\
\hline $\begin{array}{c}\text { Overall mean score } \\
\text { performance in Biology }\end{array}$ & $\begin{array}{c}\text { Equal variance } \\
\text { assumed }\end{array}$ & 1.124 & .293 & -8.54 & 60 & .000 \\
\hline $\begin{array}{c}\text { Overall mean score } \\
\text { performance in Physics }\end{array}$ & $\begin{array}{c}\text { Equal variance } \\
\text { assumed }\end{array}$ & 1.53 & .221 & -.12 & 71 & .904 \\
\hline
\end{tabular}

Table 5: Independent T-Test Output

On the average, students taking chemistry in the on-campus mode of learning performed higher $(\mathrm{M}=59.47)$ than their counterparts in ODL ( $\mathrm{M}=51.73)$. This difference was significant $\mathrm{t}(44)=-4.427, \mathrm{p}<05$. There was therefore sufficient evidence to reject the null hypothesis that there is no significant difference in performance in Chemistry between ODL and on-campus students. The on-campus students thus performed significantly better than the ODL students. In Biology, students in the on-campus mode of learning performed better $(\mathrm{M}=58.61)$ than students in the ODL mode of learning $(\mathrm{M}=48.31)$. This difference was significant $\mathrm{t}(60)=-8.54, \mathrm{p}<05$. Just like in Chemistry, there was sufficient evidence to reject the null hypothesis that there is no significant difference in performance in Biology between ODL and on-campus students. In Physics, the on-campus students performed significantly better $(\mathrm{M}=54.22)$ than ODL students $(\mathrm{M}=54.04)$. However, Table 5 shows that there was no sufficient evidence to reject the null hypothesis. Though the overall mean performance for the on-campus students was higher than for the ODL students, this difference was not significant $t$ ( 71) $=$ $.12, \mathrm{p}>.05$.

\subsection{Hypothesis 2: Relationship between Mode of Learning and Academic Performance}

The relationship between the overall mean score performance and the mode of learning was determined using Pearson correlation coefficient, $r$. This was followed by $t$-test to determine whether the difference in means was significant as shown. This is presented in Table 5.

\begin{tabular}{|c|c|}
\hline Subject & r value \\
\hline Chemistry & $0.55 ; \mathrm{p}<01$ \\
\hline Biology & $0.741 ; \mathrm{p}<01$ \\
\hline Physics & $0.014 ; \mathrm{p}>05$ \\
\hline
\end{tabular}

Table 6: Significant Tests of the Relationship between Modes of

Learning and Academic Performance

As shown in Table 6, in Chemistry and Biology, the relationship between the mode of learning and academic performance was positive and also significant. However, in Physics there is almost no linear relationship between the mode of learning an academic performance, $r=.014$. This relationship is also not significant $p>.05$. This implies that performance in Physics is independent of the mode of learning. Physics students in the ODL may be said to learn as much as their counterparts in the on-campus mode of learning.

\subsection{Hypothesis 3: Relationship between Age and Academic Performance}

As shown in Table 1, age was categorized into age groups that varied from 19 years and below to above 50 years with a class interval of 5 . To determine the relationship between age and academic performance, the researchers determined the Mean (M) score performance of students in the various age groups per mode. This is presented in Tables $7 \mathrm{a}$ for the ODL students and 7b for the on-campus students.

\begin{tabular}{|c|c|c|c|c|c|c|c|c|c|}
\hline \multirow{2}{*}{ Age group } & \multicolumn{4}{|c|}{ Chemistry } & \multicolumn{3}{c|}{ Biology } & \multicolumn{3}{c|}{ Physics } \\
\cline { 2 - 10 } & $\mathrm{N}$ & $\mathrm{M}$ & $\mathrm{SD}$ & $\mathrm{N}$ & $\mathrm{M}$ & $\mathrm{SD}$ & $\mathrm{N}$ & $\mathrm{M}$ & $\mathrm{SD}$ \\
\hline $20-24$ & 2 & 49.67 & 6.84 & 1 & 47.22 & - & 0 & - & - \\
\hline $25-29$ & 2 & 56.92 & 2.36 & 7 & 48.70 & 5.02 & 0 & - & - \\
\hline $30-34$ & 5 & 50.73 & 4.82 & 15 & 47.96 & 4.78 & 7 & 53.35 & 6.29 \\
\hline $35-39$ & 1 & 50.42 & - & 5 & 49.07 & 2.94 & 5 & 55.00 & 5.88 \\
\hline
\end{tabular}

Table 7: Mean Score Performance per Age Group in the ODL Mode of Learning $\mathrm{N}=50$ 


\begin{tabular}{|c|c|c|c|c|c|c|c|c|c|}
\hline \multirow{2}{*}{ Age group } & \multicolumn{3}{|c|}{ Chemistry } & \multicolumn{3}{c|}{ Biology } & \multicolumn{3}{c|}{ Physics } \\
\cline { 2 - 10 } & $\mathrm{N}$ & $\mathrm{M}$ & $\mathrm{SD}$ & $\mathrm{N}$ & $\mathrm{M}$ & $\mathrm{SD}$ & $\mathrm{N}$ & $\mathrm{M}$ & SD \\
\hline $20-24$ & 30 & 59.84 & 4.85 & 27 & 59.06 & 4.92 & 48 & 54.15 & 4.87 \\
\hline $25-29$ & 5 & 58.90 & 4.44 & 7 & 56.89 & 5.36 & 12 & 54.85 & 4.34 \\
\hline $30-34$ & 0 & - & - & 0 & - & - & 1 & 50.22 & - \\
\hline $35-39$ & 1 & 51.00 & - & 0 & - & - & 0 & - & - \\
\hline
\end{tabular}

Table 8: Mean Score Performance Per Age Group in the On-Campus Mode of Learning

$\mathrm{N}=131$

Table 7 shows that in Chemistry, the mean score performance for the ODL students aged between 25-29 years was higher $(\mathrm{M}=56.92)$ than in the other age groups. In Biology and Physics, older students in the 35-39 age brackets had a higher mean score of $\mathrm{M}=49.07$ and 55.00 respectively.

In contrast, Table 8 shows than in the on-campus mode, the students in the 20-24 age brackets had a higher mean score in Chemistry and Biology. In Physics, the 25-29 age brackets had a higher mean score (M=54.85). In this mode there was only 1 student aged between 35-39 years.

To determine whether the relationship between performance and age was significant (Hypothesis 3), the researchers used Chi-square test. The findings are presented in Table 8

\begin{tabular}{|c|c|c|c|c|c|}
\hline \multicolumn{2}{|c|}{} & $\begin{array}{c}\text { Mode of } \\
\text { Learning }\end{array}$ & $\begin{array}{c}\text { Overall Performance } \\
\text { in Chemistry }\end{array}$ & $\begin{array}{c}\text { Overall Performance } \\
\text { in Biology }\end{array}$ & $\begin{array}{c}\text { Overall } \\
\text { Performance } \\
\text { in Physics }\end{array}$ \\
\hline \multirow{6}{*}{ Age } & Pearson $\chi 2$ & ODL & 2.92 & 1.59 & .15 \\
& df & & 3 & 3 & 2 \\
Asymp. Sig (2- & sided) & & .41 & .66 & .93 \\
\cline { 2 - 6 } & N & & 10 & 28 & 12 \\
& $\begin{array}{c}\text { Pearson } \chi 2 \\
\text { df }\end{array}$ & On- & 1.36 & .39 & .71 \\
& $\begin{array}{c}\text { Asymp. Sig (2- } \\
\text { sided) }\end{array}$ & & 6 & 2 & 4 \\
& campus & .97 & .82 & .95 \\
& & 36 & 34 & 61 \\
\hline
\end{tabular}

Table 9: Relationship Between Age Group And Academic Performance

As Table 9 shows, there is no significant relationship between age group and academic performance of students in the ODL and in the on-campus mode of learning; $p>05$. This indicates that both the young and the old have the capability to learn and perform well in all the three sciences. This finding gave sufficient evidence to fail to reject the null that there is no significant relationship between age and academic performance between B.Ed. (Science) on-campus and ODL students.

This finding contradicts Okoh's (2010) finding that distance study students perform better than on-campus students because cognitive development and maturity which are associated with age are necessary for a worthwhile performance of the students. However, King and Doerfert (1995) had found a no significant difference on academic performance based on age; $p=654 ; p>05$. These scholars (King and Doerfert) explained this observation that at adolescent, the individual brain is fully developed and can get involved in complex as well as abstract thinking. On the other hand, older students tend to be more focused, self-driven and self-motivated to learn.

\section{Conclusions}

This study has shown that the on-campus students performed significantly better than the ODL. There was thus sufficient evidence to reject the null hypothesis that there is no significant difference in academic performance between B.Ed. (Science) on-campus and ODL student. However, in Physics there was no significant difference in the mean score performance. Secondly, age does not influence academic performance. The older ODL students can perform as well as the youthful on-campus students. Therefore, enhanced academic performance may be a matter of personal determination rather than age determined.

\section{Recommendations}

Though the older students (ODL) are encumbered with other nonacademic pressing needs that calls for their attention, they need to be encouraged to gain confidence that even in their advanced age; they have the potential to grasp scientific concepts as well as the younger students. On the other hand, the younger students, though concentrate on their academic work may not have experience to effectively meet the challenges required for enhanced academic work. The University should adopt open learning where no student should be denied entry based on their age.

\section{References}

i. Clinton, H.R. (2005). Help for the Growing Ranks of Non-traditional Students. Chronicle of Higher Education, p. B7

ii. Ding, X. (1999). A Comparative Study of Distance Higher Education Systems in Australia and China. (Unpublished $\mathrm{PhD}$ Thesis). Zentrales Institut fur Fernstudienforschung, (ZIFF), Germany 
iii. King, J. C., \& Doerfert, D. L. (1995). Interaction in the distance education setting. Paper presented at the 21st annual National Agricultural Education Research Meeting, Denver, CO. Retrieved from http://www. ssu.missouri.edu/ ssu/ aged/ naerm/ s-e-4.htm

iv. Mapuva, J. (2009). Confronting challenges to e-learning in higher education institutions,

v. International Journal of Education and Development using Information and Communication Technology (IJEDICT), 5(3). 101-114. Retrieved from http:/ / ijedict.dec.uwi.edu/ viewarticle.php?id=732

vi. McEvoy, G. M. (1989). Cumulative evidence of the relationship between employee age and job performance. Journal of Applied Psychology, 74 (4), 11-17., G. M. (1989). Cumulative evidence of the relationship between employee age and job performance. Journal of Applied Psychology, 74 (4), 11-17.

vii. Mills, R. \& Tait, A. (1999). The Convergence of Distance and Conventional Education. NewYork: Routledge

viii. Neumann, Y., \& Shachar, M. (2003). Differences between Traditional and Distance

ix. Academic Performance: A meta-analytic approach. Journal of International Review of Research in Open and Distance Learning, Vol. 4, No. 2, pp 19-40

x. Okoh-Ebenuwa, E.E. (2010). Influence of Age, Financial Status and Gender on Academic Performance among Undergraduates. Journal of Psychology, Vol. 1, No. 2, pp. 99-103

xi. Powell, R., McGuire, S., \& Crawford, G. (1999). Convergence of Student Types: issues for Distance Education. In Mills, R. \& Tait, A. (Ed), The Convergence of Distance and Conventional Education. New York: Routledge, pp. 86-89

xii. Unterberg, M. (2003). Do Learning Style and Learning Environment Affect the Learning Outcome? Journal of Physical therapy education (St. Louis, Maryville University), Vol. 3(8), pp. 67-75 